\title{
Rekognisi Publik Pengguna Pelayanan Akuntan Terhadap Tingkat Moralitas Akuntan Publik
}

\author{
Muhammad Reza Ramdani*, Ismi Ayu Lestari
}

Fakultas Ekonomi Universitas Muslim Indonesia, Indonesia

*Email korenpondensi: reza.ramdani@umi.ac.id

\begin{abstract}
This study aims to determine the public perception of public accountant service users to the level of integrity of public accountants. Where the public users of public accounting services or the users of financial statements consists of internal parties represented by directors or managers of companies go public and external parties represented by investors and creditors who are respectively securities firms and conventional banks in the city. The research method used descriptive qualitative approach through the process of observation and spreading questionnaire (questionnaire). Primary data obtained through the distribution of questionnaires to respondents' public users of public accounting services. The rate of return of questionnaires was $95.3 \%$ or 41 questionnaires from 43 questionnaires distributed. The result of the research shows that public perception of public accountant service user to integrity of public accountant either show positive value or most give answer agree on questionnaire sheet. So this research concludes that public perception of public accountant service user to integrity level of public accountant in ity is positive or still in high level of integrity
\end{abstract}

Keywords: Perception, Integrity, KAP

Saran sitasi: Ramdani, M., \& Lestari, I. (2019). Rekognisi Publik Pengguna Pelayanan Akuntan Terhadap Tingkat Moralitas Akuntan Publik. Jurnal Akuntansi dan Pajak, 19(2), 170-184. doi:http://dx.doi.org/10.29040/jap.v19i2.269

DOI: http://dx.doi.org/10.29040/jap.v19i2.269

\section{Pendahuluan}

Etika profesi menjadi tolok ukur kepercayaan masyarakat terhadap suatu profesi (Jusup, 2001). Tidak terkecuali profesi akuntan publik. Di Amerika, kode etik mengenai akuntan publik diatur oleh American Institute of Certified Public Accountants (AICPA) di mana salah satu peraturan kode etiknya, yakni peraturan 102 membahas tentang integritas dan objektivitas (Alvin, Ellder, \& Beasley, 2008). Di Indonesia sendiri, kode etik akuntan publik diatur oleh Institut Akuntan Publik Indonesia (IAPI) yang mengadopsi kode etik profesional AICPA, yang juga salah satu peraturannya membahas mengenai integritas. Sedangkan menurut Josephen
Institute yang dikutip oleh Alvin, Ellder, \& Beasley (2008), integritas berarti bahwa seseorang bertindak sesuai dengan kesadaran yang tinggi, dalam situasi apapun. Integritas adalah unsur karakter yang mendasar bagi pengakuan profesional.Integritas merupakan kualitas yang menjadikan timbulnya kepercayaan masyarakat dan tatanan nilai tertinggi bagi anggota profesi dalam menguji semua keputusannya. Integritas mengharuskan auditor, dalam berbagai hal, jujur dan terus terang dalam batasan kerahasiaan objek pemeriksaan. Pelayanan dan kepercayaan masyarakat tidak dapat dikalahkan demi kepentingan dan keuntungan pribadi (Agoes \& Ardana, 2009). 
Akuntan publik berada dalam konflik audit, Konflik ini akan menjadi sebuah dilema etika ketika auditor diharuskan membuat keputusan yang menyangkut integritas dan independensinya dengan imbalan ekonomis yang mungkin dijanjikan di sisi lainnya. Karena auditor seharusnya secara sosial juga bertanggung jawab kepada masyarakat dan profesinya daripada mengutamakan kepentingan dan pertimbangan pragmatis pribadi atau kepentingan ekonomi semata, sering kali auditor dihadapkan pada dilema etika dalam pengambilan keputusannya (Lubis, 2010). Hasil ini sama dengan temuan yang menyatakan kami menemukan manajer kredit kurang peduli pada independensi auditor pada semua empat situasi terkait dengan kepemilikan saham (Rodgers, Mubako, \& Hall, 2017). Kondisi ini menjadi fenomena kurang persepsi masyarakat pengguna jasa akuntan publik. Hal ini mengharuskan auditor untuk menghindari situasi yang dapat menyebabkan orang lain menyimpulkan bahwa mereka memang demikian tidak mempertahankan sikap objektif pikiran (Porter, Simon, \& Hatherly, 2003).

Beberapa kasus di mana akuntan publik gagal di dalam mempertahankan integritasnya atau gagal di dalam menghadapi dilema etika. Pada kutipan pada media Warta Ekonomi tahun 2008, KAP Ernst \& Young dituntut oleh jaksa New York atas tuduhan membantu menyembunyikan masalah keuangan Lehman Brothers, perusahaan sekuritas terbesar keempat di Amerika. Tuntutan hukum tersebut meminta tanggung jawab US\$ 150 juta, yaitu sejumlah biaya yang diterima Ernst \& Young dari tahun 2001 sampai 2008 sebagai auditor Lehman Brothers. Kasus Ernst \& Young yang diajukan Andrew Cuomo itu adalah salah satu kasus hukum terbesar yang melibatkan kantor akuntan sejak kasus Enron yang melibatkan Arthur Anderson. Untuk beberapa kasus di Indonesia berikut diantaranya, menteri keuangan (Menkeu) RI terhitung sejak tanggal 28 November 2006 telah membekukan izin Akuntan Publik (AP) Justinus Adytia Sidharta selama dua tahun. Sanksi tersebut diberikan karena Justinus terbukti melakukan pelanggaran terhadap Standar Profesional Akuntan Publik (SPAP) berkaitan dengan laporan audit atas laporan keuangan konsolidasi PT. Great River Internasional Tbk (Great River) tahun 2003.

KAP mitra Ernst \& Young di Indonesia pada 9 Februari 2017 yakni KAP Purwantono, Suherman \& Surja sepakat membayar denda senilai US\$ 1 juta kepada regulator Amerika Serikat, akibat divonis gagal melakukan audit laporan keuangan kliennya. Temuan ini berawal ketika kantor akuntan mitra Ernst \& Young di Amerika melakukan kajian atas hasil audit kantor akuntan di Indonesia. Mereka menemukan bahwa hasil audit dari salah satu perusahaan telekomunikasi di Indonesia tidak didukung dengan data yang akurat, yakni dalam hal penyewaan lebih dari empat ribu unit tower seluler. Pengawas Perusahaan Akuntan Publik Amerika Serikat (Public Company Accounting Oversight Board/PCAOB) selain mengenakan denda US\$1 juta juga memberikan sanksi kepada dua auditor mitra Ernst \& Young tersebut. Pelanggaran-pelanggaran tersebut kemungkinan dapat mempengaruhi persepsi masyarakat. Terutama masyarakat pembaca laporan keuangan seperti manajer, investor dan kreditor. Masyarakat pembaca laporan keuangan bahkan berharap profesi akuntan publik tidak hanya sekedar menilai kewajaran penyajian laporan tapi juga kewajaran transaksi yang dilaporkan. Harapan ini mengandung tuntutan agar profesi akuntan publik berpihak pada kepentingan pembaca laporan keuangan.

Berdasarkan uraian di atas, dapat dilihat bahwa ada hubungan yang kuat antara orang Indonesia, profesi akuntansi dan negara (Bachtiar, 2001). Maka peneliti merasa perlu untuk meneliti bagaiman apersepsi masyarakat pengguna jasa akuntan publik, yakni pihak manajer, kreditor dan investor sebagai pengguna laporan keuangan yang telah diaudit terhadap tingkat integritas akuntan publik di kota Makassar, terutama di dalam era sekarang, dengan segala kompleksitas akuntansi yang ada.Penelitian ini merupakan kelanjutan dari beberapa penelitian terdahulu. 
Salah satunya adalah penelitian yang dilakukan oleh Suhardi (2012) yang meneliti tentang Persepsi pemakai laporan keuangan pemerintah daerah terhadap independensi auditor Badan Pemeriksa Keuangan.

Berdasarkan argumen di atas, maka peneliti mereplikasi penelitian sebelumnya yang dilakukan (Rodgers, et al., 2017). Adapun beberapa perbedaan atau diferensiasi yang akan dilakukan oleh peneliti dari penelitian sebelumnya adalah pertama, tempat penelitian terdahulu dilakukan di Surabaya dan kali ini dilakukan di Makassar. Kedua, pada penelitian mengambil dari dua segi persepsi yakni dari persepsi masyarakat, khususnya masyarakat pengguna jasa akuntan publik dan auditor yang bekerja di kantor akuntan publik (KAP) dan penelitian sekarang hanya mengambil dari segi persepsi masyarakat pengguna jasa akuntan publik. Ketiga, adapun metode analisis penelitian adalah melakukan uji beda, sedangkan pada penelitian kali ini menggunakan metode analisis deskriptif.

\section{Tinjauan Pustaka}

\subsection{Persepsi}

Kunci untuk memahami persepsi adalah mengakui bahwa persepsi merupakan interpretasi unik dari suatu situasi, bukan rekaman situasi. Singkatnya, persepsi merupakan proses kognitif kompleks yang menghasilkan gambaran dunia yang unik, yang mungkin agak berbeda dari realita (Fred, 2006).

Riset tentang persepsi secara konsisten menunjukkan bahwa individu yang berbeda dapat melihat hal yang sama tetapi memahaminya secara berbeda. Kenyataannya adalah bahwa tak seorang pun dari kita melihat realitas. Yang kita lakukan adalah menginterpretasikan apa yang kita lihat dan menyebutnya sebagai realitas (Robbins \& Judge, 2008). Persepsi (perception) adalah proses dimana individu mengatur dan menginterpretasikan kesan-kesan sensoris mereka guna memberikan arti bagi lingkungan mereka. Namun apa yang diterima seseorang pada dasarnya bisa berbeda dari realita objektif. Walaupun seharusnya tidak perlu ada, perbedaan tersebut sering timbul (Robbins \& Judge, 2008).

Chaplin (2006) dalam kamus lengkap psikologi mengatakan bahwa, persepsi adalah proses mengetahui atau mengenali objek dan kejadian objektif dengan bantuan indera. Dalam psikologi kontemporer, persepsi secara umum diperlakukan sebagai suatu variabel campur tangan (intervening variable), bergantung pada faktor-faktor perangsang, cara belajar, perangkat, keadaan jiwa atau suasana hati, dan faktor-faktor motivasional.

Lubis (2010), persepsi adalah bagaimana orang-orang melihat atau menginterpretasikan peristiwa, objek, serta manusia. Persepsi merupakan suatu proses yang melibatkan pengetahuanpengetahuan sebelumnya dalam memperoleh dan menginterpretasikan stimulus yang ditunjukkan oleh pancaindra. Dengan kata lain, persepsi merupakan kombinasi antara faktor utama dunia luar (stimulus visual) dan diri manusia itu sendiri (pengetahuan-pengetahuan sebelumnya). Persepsi memberikan makna pada stimuli (sensor stimuli). Persepsi juga merupakan pengalaman tentang objek atau hubungan-hubungan yang diperoleh dengan menyimpulkan informasi dan menafsirkan pesan. Meskipun demikian, karena persepsi tentang objek atau peristiwa tersebut bergantung kepada kerangka ruang dan waktu, maka persepsi akan bersifat sangat subjektif dan situasional. Persepsi ditentukan oleh faktor personal dan situasional. Faktor fungsional berasal dari kebutuhan, pengalaman masa lalu, dan hal-hal lain yang termasuk dalam faktor fungsional. Oleh karena itu, yang menentukan persepsi bukanlah jenis atau stimuli, tetapi karakteristik orang yang memberikan respons terhadap stimuli tersebut. Sementara itu, faktor struktural berasal dari sifat fisik dan dampak saraf yang ditimbulkan pada sistem saraf individu. Persepsi dikatakan rumit dan aktif karena walaupun persepsi merupakan pertemuan antara proses kognitif dan kenyataan, persepsi lebih banyak melibatkan kegiatan kognitif. Persepsi lebih banyak dipengaruhi oleh kesadaran, ingatan, pikiran, dan bahasa. Dengan 
demikian, persepsi bukanlah cerminan yang tepat dari realitas (Lubis, 2010).

\subsection{Masyarakat Pengguna Laporan \\ Keuangan}

Faktor kunci citra profesi akuntan publik, yaitu keberadaan dan perkembangan profesi akuntan itu sendiri ditentukan oleh tingkat kepercayaan masyarakat pemakai jasa akuntan publik, sedangkan tingkat kepercayaan masyarakat di tentukan oleh tingkat kualitas jasa (pengetahuan dan keterampilan teknis di bidang akuntansi serta disiplin ilmu yang terkait) dan tingkat ketaatan serta kesadaran akuntan publik dalam mematuhi kode etik profesi (Agoes \& Ardana, 2009).

\subsection{Profesi Akuntan Publik}

Akuntan Publik atau juga dikenal sebagai akuntan eksternal adalah akuntan independen yang memberikan jasa-jasanya atas dasar pembayaran tertentu. Mereka bekerja bebas dan umumnya mendirikan suatu kantor akuntan. Kantor akuntan publik bertanggung jawab mengaudit laporan keuangan historis yang dipublikasikan oleh semua perusahaan terbuka, kebanyakan perusahaan lain yang cukup besar, dan banyak perusahaan serta organisasi nonkomersial yang lebih kecil (Alvin, Ellder, \& Beasley, 2008). Peraturan Menteri Keuangan RI Nomor 17/PMK. 01/2008 tentang jasa akuntan publik, di dalam pasal 1 (satu) menyebutkan bahwa :

1. Akuntan Publik adalah akuntan yang telah memperoleh izin dari Menteri untuk memberikan jasa sebagaimana diatur dalam Peraturan Menteri Keuangan ini.

2. Kantor Akuntan Publik yang selanjutnya disebut KAP, adalah badan usaha yang telah mendapatkan izin dari Menteri sebagai wadah bagi Akuntan Publik dalam memberikan jasanya.

Kemudian di dalam pasal 2, meyebutkan mengenai bidang jasa akuntan publik meliputi:

1. Bidang jasa Akuntan Publik dan KAP adalah atestasi, yang meliputi:

a. Jasa audit umum atas laporan keuangan; b. Jasa pemeriksaan atas laporan keuangan prospektif;

c. Jasa pemeriksaan atas pelaporan informasi keuangan proforma;

d. Jasa review atas laporan keuangan; dan

e. Jasa atestasi lainnya sebagaimana tercantum dalam SPAP.

2. Selain jasa sebagaimana yang dimaksud pada ayat (1), Akuntan Publik dan KAP dapat memberikan jasa audit lainnya dan jasa yang berkaitan dengan akuntansi, keuangan, manajemen, kompilasi, perpajakan, dan konsultasi sesuai dengan Kompetensi Akuntan Publik dan peraturan perundang- undangan yang berlaku.

\subsection{Kode Etik Profesi Akuntan Publik Indonesia}

Agoes dan Ardana (2009) menyatakan bahwa faktor kunci citra profesi akuntan salah satunya ditentukan dari tingkat ketaatan serta kesadaran para akuntan dalam mematuhi kode etik profesi akuntansi.Dengan membuat kode etik, profesi sendiri akan menetapkan hitam atas putih niatnya untuk mewujudkan nilai-nilai moral yang dianggapnya hakiki. Hal ini tidak akan pernah bisa dipaksakan dari luar. Interpretasi Aturan Etika merupakan penafsiran, penjelasan, atau elaborasi lebih lanjut atas halhal, isu-isu, dan pasal-pasal yang diatur dalam Aturan Etika, yang dianggap memerlukan penjelasan agar tidak terjadi perbedaan pemahaman atas aturan etika yang dimaksud. Pada tingkat paling bawah, dimungkinkan adanya tanya-jawab yang berkaitan dengan isu-isu etika.Tanya jawab ini dapat dilakukan dengan Dewan Standar Profesi yang dibentuk oleh pengurus kompartemen/ institut yang bersangkutan (Agoes \& Ardana, 2009). Gambar 1 merupakan strukutur/rerangka kode etik IAI dengan IAI-KAP (sekarang bernama Ikatan Akuntan Publik Indonesia-IAPI).

Pada penelitian ini, peneliti akan lebih berfokus kepada salah satu Prinsip Etika Ikatan Akuntan Indonesia (IAI) dan salah satu aturan dalam IAI-KAP/ Ikatan Akuntan Publik Indonesia (IAPI), yakni mengenai Integritas. 


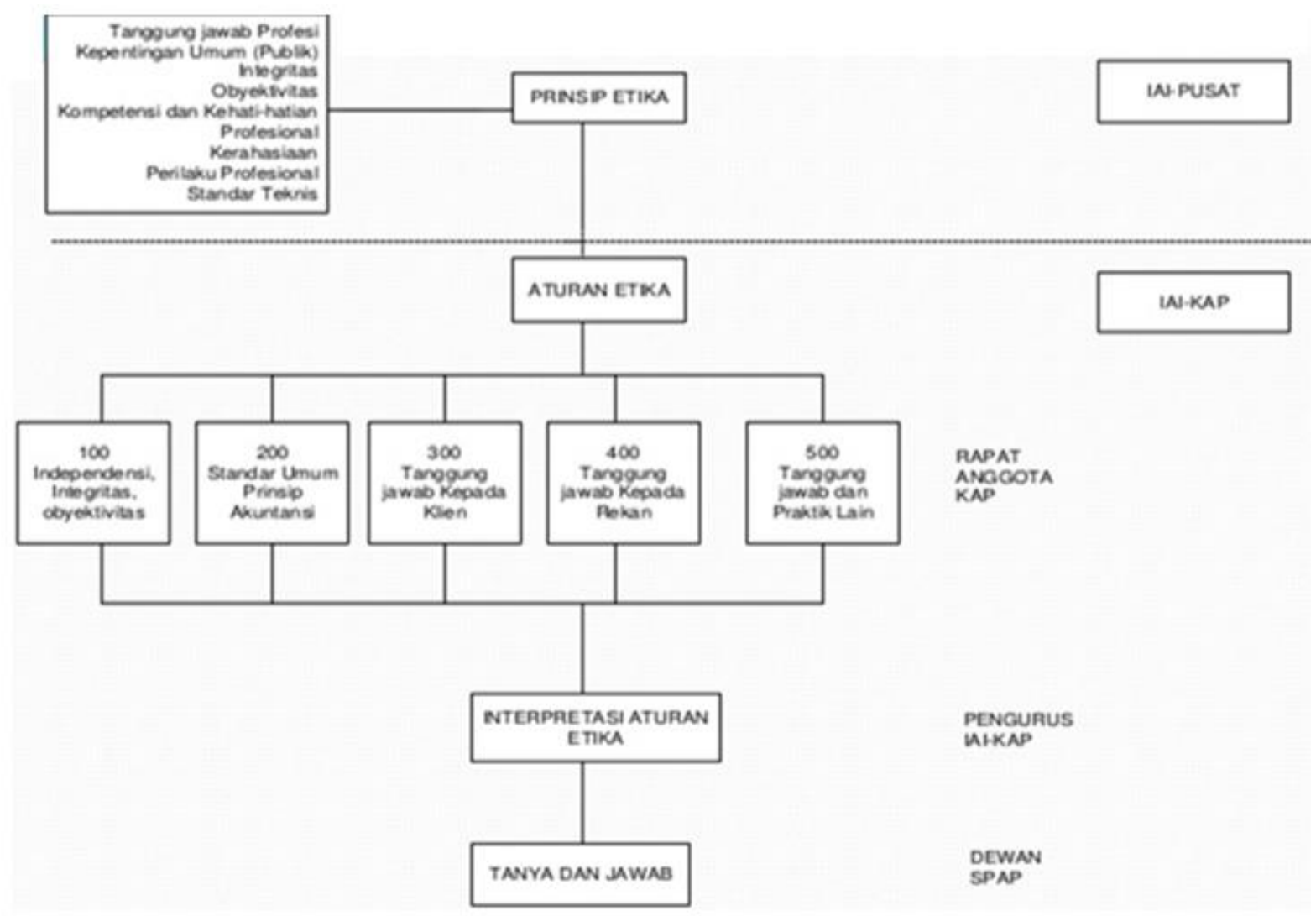

Gambar 1. Rerangka Kode Etik IAI dan IAPI Sumber: SPAP (Agoes \& Ardana, 2009).

\subsection{Integritas}

Di dalam Prinsip Etika Ikatan Akuntan Indonesia (IAI) pada prinsip ketiga mengenai integritas disebutkan bahwa, untuk memelihara dan meningkatkan kepercayaan publik, setiap anggota harus memenuhi tanggung jawab profesionalnya dengan integritas setinggi mungkin. Dari pernyataan tersebut, dapat diuraikan bahwa:

1. Integritas adalah suatu elemen karakter yang mendasari timbulnya pengakuan profesional. Integritas merupakan kualitas yang melandasi kepercayaan publik dan merupakan patokan (benchmark) bagi anggota dalam menguji semua keputusan yang diambilnya.

2. Integritas mengharuskan seorang anggota untuk, antara lain, bersikap jujur dan berterus terang tanpa harus mengorbankan rahasia penerima jasa. Pelayanan dan kepercayaan publik tidak boleh dikalahkan oleh keuntungan pribadi. Integritas dapat menerima kesalahan yang tidak disengaja dan perbedaan pendapat yang jujur, tetapi tidak dapat menerima kecurangan atau peniadaan prinsip.

3. Integritas diukur dalam bentuk apa yang benar dan adil. Dalam hal tidak terdapat aturan, standar, panduan khusus atau dalam menghadapi pendapat yang bertentangan, anggota harus menguji keputusan atau perbuatannya dengan bertanya apakah anggota telah melakukan apa yang seorang berintegritas akan lakukan dan apakah anggota telah menjaga integritas dirinya. Integritas mengharuskan anggota untuk menaati baik bentuk maupun jiwa standar teknis dan etika.

4. Integritas juga mengharuskan anggota untuk mengikuti prinsip objektivitas dan kehatihatian profesional.

\section{Metode Penelitian}

\subsection{Populasi dan sampel}

Responden yang berasal dari masyarakat pengguna jasa akuntan publik, untuk pihak internal pengguna laporan keuangan akan diwakili olehdirektur atau manajer beberapa perusahaan go publik yang terdaftar di Bursa 
Efek Indonesia (BEI) di kota Makassar. Untuk pihak eksternal pengguna laporan keuangan kreditor akan diwakili oleh kepala cabang bankbank konvensional dan pihak investor akan diwakilioleh perusahaan sekuritas yang berada di kota Makassar. Adapun waktu penelitian sekitar 10 (sepuluh) bulan yang berlangsung dari bulan Maret sampai dengan Desember 2017.

Populasi dalam penelitian kali ini adalah masyarakat pengguna jasa akuntan publik yang diwakili oleh pihak direktur atau manajer, pihak kreditor yang diwakili oleh kepala cabang bank dan investor yang diwakili oleh perusahaan sekuritas.

Untuk masyarakat pengguna jasa akuntan publik, berikut adalah tabel jumlah perusahaan Go Public yang terdaftar di Bursa Efek Indonesia, perusahaan sekuritas dan bank yang berada di Kota Makassar.

Tabel 1. Jumlah Populasi Penelitian Masyarakat Pengguna Jasa Akuntan Publik di Kota Makassar

\begin{tabular}{|c|c|c|}
\hline No & $\begin{array}{c}\text { Masyarakat Pengguna Jasa } \\
\text { KAP }\end{array}$ & Jumlah \\
\hline 1 & $\begin{array}{l}\text { Perusahaan Go Publicyang } \\
\text { terdaftar di BEI }\end{array}$ & 65 \\
\hline 2 & Perusahaan sekuritas & 16 \\
\hline \multirow[t]{2}{*}{3} & Kantor cabang utama bank & 53 \\
\hline & Total & 134 \\
\hline
\end{tabular}

Sampel terdiri dari sejumlah anggota yang dipilih dari populasi. Hal ini dilakukan mengingat kendala biaya, waktu, dan tenaga serta masalah heteroginitas dan homogenitas dari elemen populasi.

Penelitian ini, menggunakan penentuan sampel yang dikemukakan Slovin diterjemahkan oleh Husein (2009) yaitu :

Keterangan :

$$
n=\frac{\mathrm{N}}{1+\mathrm{N}(\mathrm{e})^{2}}
$$

$n$ = Jumlah Sampel

$\mathrm{N}=$ Jumlah Populasi

$\mathrm{e} \quad=$ Margin of Error (kesalahan maksimum

yang bisa ditolerir sebesar 10 persen).
Pemakaian rumus diatas mempunyai asumsi bahwa populasi berdistribusi normal.

$$
\begin{aligned}
& n=\frac{134}{1+134(0,1)^{2}} \\
& n=57,264 \text { (pembulatan57 orang) }
\end{aligned}
$$

Seperti yang dikemukakan oleh Roscoe yaitu :

1. Jumlah sampel yang tepat dalam penelitian adalah $30<\mathrm{n}<500$.

2. Jika sampel terbagi dalam beberapa subsampel, maka jumlah sampel minimum untuk tiap subsampel adalah 30 (Sartika, 2006)

Tetapi setelah melakukan proses penelitian lanjutan, dengan mempertimbangkan ketersediaan waktu, biaya, luas wilayah dan persetujuan tempat yang akan diteliti. Maka jumlah sampel penelitian yang semula 57 responden menyusut menjadi 43 responden.

\subsection{Metode Pengumpulan Data}

1. Observasi, Dimana sebelum melakukan penelitian lanjutan, peneliti terlebih dahulu melakukan observasi ke tempat yang akan dijadikan objek penelitian. Pada proses observasi, selain peneliti melakukan proses pengamatan fisik atau tempat, proses kerja, struktur organisasi tempat yang akan diteliti, peneliti juga menanyakan ketersediaan tempat yang akan diteliti. Keseluruhan hal tersebut didokumentasikan di dalam sekumpulan catatan tertulis dan media elektronik oleh peneliti.

2. Kuesioner (angket), Kuesioner yang diajukan kepada responden berupa daftar pertanyaan tertutup (closed questions), yaitu pertanyaan yang dibuat sedemikian rupa sehingga responden dibatasi untuk membuat pilihan di antara serangkaian alternatif saja. Terdapat 43 kuesioner yang disebar berdasarkan jumlah sampel atau respondenpenelitian, dimana terdiri dari 20 kuesioner untuk manajer atau direktur perusahaan go public, tiga kuesioner untuk perusahaan sekuritas dan 20 kuesioner untuk kepala cabang bank yang berada di kota Makassar. 


\subsection{Metode Analisis Data}

Penelitian akan dimulai pengujian validitas dan reliabilitas terhadap daftar pertanyaan yang digunakan dalam kuesioner.

1. Pengujian Validitas.

Model pengujian menggunakan pendekatan Pearson Correlation untuk menguji validitas pernyataan kuesioner yang disusun dalam bentuk skala. Syarat minimum untuk dianggap memenuhi syarat validapabila nilai $\mathrm{r}_{\text {hitung }}>\mathrm{r}_{\text {tabel }}$ pada taraf signifikansi sebesar $5 \%$ atau 0,05 .

2. Pengujian Reliabilitas

Reliabilitas instrumen diperlukan untuk mendapatkan data yang sesuai dengan tujuan pengukuran. Untuk mencapai hal tersebut, dilakukan uji reliabilitas dengan menggunakan metode Cronbach Alpha (a). Koefisien cronbach alpha yang lebih besar dari 0,6 menunjukkan keandalan (reliabilitas) instrument.

Metode analisis menggunkan pendekatan Statistik Deskriptif. Statistik deskriptif hanya berhubungan dengan hal menguraikan atau memberikan keterangan- keterangan mengenai suatu data, keadaan atau fenomena. Dengan kata lain statistik deskriptif berfungsi menerangkan keadaan, gejala atau persoalan. Penarikan kesimpulan pada statistik deskriptif hanya ditujukan pada kumpulan data yang ada.

\subsection{Definisi Operasional Variabel Penelitian}

Variabel yang digunakan dalam penelitian ini adalah sebagai berikut:

1. Persepsi, menurut Robbins dan Judge (2008) adalah proses dimana individu mengatur dan menginterpretasikan kesan-kesan sensoris mereka guna memberikan arti bagi lingkungan mereka. Sementara Lubis (2010) mendefinisikan persepsi yaitu bagaimana orang-orang melihat atau menginterpretasikan peristiwa, objek, serta manusia.

2. Masyarakat pengguna jasa akuntan publik adalah pihak-pihak, baik secara langsung maupun tidak lagsung yang membutuhkan laporan opini dari auditor (auditor eksternal) guna lebih meyakinkan tingkat reliabilitas laporan keuangan yang telah disajikan agar pengambilan keputusan ekonomi suatu entitas tepat sasaran. Dimana di dalam penelitian kali ini, pihak masyarakat pengguna jasa akuntan publik akan diwakili oleh pihak direktur atau manajer, kreditor dan investor.

3. Integritas Akuntan Publik, Salah satu elemen yang terdapat di Kode Etik Profesi Akuntan Publik adalah integritas. Integritas adalah suatu elemen karakter yang mendasari timbulnya pengakuan profesional. Integritas merupakan kualitas yang melandasi kepercayaan publik dan merupakan patokan (benchmark) bagi anggota dalam menguji semua keputusan yang diambilnya.

Integritas pada penelitian ini yaitu terdapat pada Prinsip Ketiga Etika IAI, Aturan Etika IAI Nomor 100 dan dalam Interpretasi Aturan Etika IAI. Sebagaimana yang diadopsi dari penelitian terdahulu Rasyid (2004), terdapat 16 pernyataan nomor 1 sampai 10 mewakili Integritas pada Prinsip Ketiga Etika IAI, pernyataan nomor 11 sampai 13 mewakili Aturan Etika IAI Nomor 100 dan pernyataan nomor 14 sampai IAP16 mewakiliInterpretasi Aturan Etika IAI. Untuk skala pengukuran setiap variabel dalam penelitian ini yaitu menggunakan Skala Likert, yaitu skala yang digunakan untuk mengukur sikap, pendapat, dan persepsi seseorang atau sekelompok orang tentang fenomena sosial (Sugiyono, 2003). Sewaktu menaggapi pertanyaan dalam skala Likert, responden menentukan tingkat persetujuan mereka terhadap suatu pertanyaan dengan memilih salah satu dari pilihan yang tersedia (1 tidak setuju - 5 sangat setuju).

\section{Hasil dan Pembahasan}

\subsection{Hasil penelitian}

Metode pengumpulan data yang digunakan dalam penelitian ini adalah penelitian lapangan (field research), yaitu metode pengumpulan data yang dilakukan dengan cara peninjauan langsung atau observasi dan membagikan kuesioner pada objek penelitian untuk mendapatkan informasi. Hasil penyebaran kuesioner untuk masingmasing sampel disajikan dalam tabel 5. 
Jurnal Akuntansi dan Pajak, 19(02), 2019, 177

Tabel 2. Rincian Kuesioner

\begin{tabular}{ccccccc}
\hline No. & $\begin{array}{c}\text { Kelompok } \\
\text { Responden }\end{array}$ & $\begin{array}{c}\text { Kuesioner } \\
\text { Disebar }\end{array}$ & $\begin{array}{c}\text { Kuesioner } \\
\text { Kembali }\end{array}$ & $\begin{array}{c}\text { Tingkat } \\
\text { Pengembalian }\end{array}$ & $\begin{array}{c}\text { Kuesioner } \\
\text { Gugur }\end{array}$ & $\begin{array}{c}\text { Kuesioner } \\
\text { Diolah }\end{array}$ \\
\hline 1 & $\begin{array}{l}\text { Masyarakat } \\
\text { Pengguna Jasa } \\
\text { Akuntan Publik }\end{array}$ & 43 & 41 & $95,3 \%$ & - & 41 \\
\hline
\end{tabular}

Sumber : Data Primer Diolah, 2018.

Adapun jumlah kuesioner yang disebar pada penelitian kali ini yaitu sebanyak 43 kuesioner yang disesuaikan dengan jumlah responden penelitian, yakni sebanyak 43 responden. Tetapi pada proses selanjutnya, dari 43 kuesioner yang disebar, terdapat 2 kuesioner yang tidak kembali, yakni satu dari pihak perusahaan go public dan satu lagi dari pihak perusahaan sekuritas. Sehingga total kuesioner yang akan diolah sebanyak 41kuesioner (95,3\%).

\subsubsection{Deskripsi Responden}

Adapun deskripsi responden masyarakat pengguna jasa akuntan publik berdasarkan jumlah dan informasi kuesioner yang akan diolah pada penelitian kali ini adalah sebagai berikut :

\section{a. Klasifikasi}

Deskripsi responden berdasarkan klasifikasinya dapat dilihat pada Tabel 3.

Tabel 3. Deskripsi Responden Berdasarkan

\begin{tabular}{|c|c|c|}
\hline \multicolumn{3}{|c|}{ Klasifikasinya } \\
\hline & $\begin{array}{l}\text { Tasyarakat Pengguna } \\
\text { asa Akuntan Publik }\end{array}$ & Jumlah \\
\hline 1. & Direktur \& Manajer & $19(46,3 \%)$ \\
\hline 2. & Investor & $2(4,9 \%)$ \\
\hline & Kreditor & $20(48,8 \%)$ \\
\hline & Total & $41(100 \%)$ \\
\hline
\end{tabular}

Berdasarkan Tabel 3, dari 41 responden masyarakat pengguna jasa akuntan publik yang berada di kota Makassar, sebanyak 19 responden ( 46,3 \%) berasal dari pihak direktur dan manajer perusahaan go public yang terdaftar di Bursa Efek Indonesia (BEI), dua responden $(4,9 \%)$ berasal dari pihak perusahaan sekuritas atau investor dan 20 responden $(48,8 \%)$ berasal dari pihak bank konvensional atau pihak kreditor. Dari ketiga kelompok responden tersebut, pengembalian kuesioner secara keseluruhan hanya berasal dari pihak kreditor.

\section{b. Jenis Kelamin}

Deskripsi responden berdasarkan jenis kelaminnya dapat dilihat pada Tabel 4.

Tabel 3. Deskripsi Responden Berdasarkan Jenis Kelamin

\begin{tabular}{|c|c|}
\hline $\begin{array}{c}\text { Masyarakat Pengguna } \\
\text { Jasa Akuntan Publik }\end{array}$ & Jumlah \\
\hline 1. Laki-laki & $31(75,6 \%)$ \\
\hline 2. Perempuan & $10(24,4 \%)$ \\
\hline Total & $41(100 \%)$ \\
\hline
\end{tabular}

Berdasarkan Tabel 4, dari 41 responden masyarakat pengguna jasa akuntan publik yang berada di kota Makassar, lebih dari 50\% atau lebih tepatnya sebanyak 31 responden ( $75,6 \%)$ adalah laki-laki. Sisanya, yakni sebanyak 10 responden ( $24,4 \%$ ) adalah perempuan. Dari tabel tersebut, dapat disimpulkan bahwa laki-laki mendominasi kedudukan atau posisi manajer /direktur perusahaan go public, perusahaan sekuritas dan kepala cabang bank konvensional di kota Makassar.

\section{c. Umur/ Usia}

Deskripsi responden berdasarkan umur atau usianya dapat dilihat pada tabel 5 .

Tabel 5. Deskripsi Responden Berdasarkan Umur/ Usia

\begin{tabular}{|c|c|}
\hline $\begin{array}{c}\text { Masyarakat Pengguna Jasa } \\
\text { Akuntan Publik }\end{array}$ & Jumlah \\
\hline 1. $\leq 25$ tahun & - \\
\hline $2 . \quad 26-30$ tahun & $7(18 \%)$ \\
\hline 3. $31-35$ tahun & $6(14,6 \%)$ \\
\hline 1. Lebih dari 35 thn & $28(67,4 \%)$ \\
\hline$\quad$ Total & $\mathbf{4 1 ( 1 0 0 \% )}$ \\
\hline
\end{tabular}

Berdasarkan Tabel 5, dari 41 responden masyarakat pengguna jasa akuntan publik, tidak ada yang berumur di bawah 25 tahun ( $0 \%$ ), yang berumur 26 sampai 30 tahun sebanyak 7 responden ( $18 \%$ ), yang berumur 31 sampai 35 tahun sebanyak 6 responden $(14,6 \%)$ dan yang di atas 35 tahun sebanyak 
28 responden (67, $4 \%$ ). Dapat disimpulkan, bahwa komposisi umur atau usia responden masyarakat pengguna jasa akuntan publik bervariasi antara 26 sampai di atas 35 tahun, dimana lebih dari $50 \%$ responden berusia di atas 35 tahun.

\section{d. Pendidikan}

Deskripsi responden berdasarkan jenjang pendidikan terakhirnya dapat dilihat pada Tabel 6.

Tabel 6. Deskripsi Responden Berdasarkan Pendidikan

\begin{tabular}{|c|c|}
\hline $\begin{array}{l}\text { Masyarakat Pengguna Jasa } \\
\text { Akuntan Publik }\end{array}$ & Jumlah \\
\hline 1. SMU & - \\
\hline 2. $\mathrm{S} 1$ & $10(24,4 \%)$ \\
\hline 3. $\mathrm{S} 2$ & $31(75,6 \%)$ \\
\hline Total & $41(100 \%)$ \\
\hline
\end{tabular}

Berdasarkan Tabel 6, dari 41 responden masyarakat pengguna jasa akuntan publik, tidak ada yang jenjang pendidikan terakhirnya SMU ( $0 \%)$, sebanyak 10 responden $(24,4 \%)$ jenjang pendidikan nya S1, dan 31 responden $(75,6 \%)$ jenjang pendidikannya S2. Kesimpulan dari tabel tersebut adalah sebagian besar responden masyarakat pengguna jasa akuntan publik telah memiliki tingkat pendidikan yang cukup baik.

e. Masa Kerja

Deskripsi responden berdasarkan masa kerjanya dapat dilihat pada Tabel 7.

Tabel 7. Deskripsi Responden Berdasarkan Masa Kerja

\begin{tabular}{cc}
\hline $\begin{array}{c}\text { Masyarakat Pengguna } \\
\text { Jasa Akuntan Publik }\end{array}$ & Jumlah \\
\hline 1. $1-5$ tahun & $16(39 \%)$ \\
2. $6-10$ tahun & $18(44 \%)$ \\
3. Lebih dari 10 thn & $7(17 \%)$ \\
Total & $41(100 \%)$ \\
\hline
\end{tabular}

Berdasarkan Tabel 7, dari 41 responden masyarakat pengguna jasa akuntan publik, sebanyak 16 responden (39\%) telah bekerja antara satu sampai lima tahun. Sebanyak 18 responden (44\%) telah bekerja antara enam sampai sepuluh tahun dan 7 responden $(17 \%)$ telah bekerja lebih dari sepuluh tahun. Dari tabel di atas, dapat disimpulkan bahwa masa kerja responden masyarakat pengguna jasa akuntan publik cukup bervariasi, yakni antara satu sampai lebih dari sepuluh tahun

\subsubsection{Uji Validitas dan Uji Realibilitas}

\section{a. Uji Validitas}

Uji validitas digunakan untuk menguji sejauh mana ketepatan alat ukur dapat mengungkapkan konsep gejala/ kejadian yang diukur. Pengujian validitas dilakukan dengan menggunakan pendekatan validitas konstruk dengan metode "Pearson Correlation". Dasar Pengambilan valid tidaknya butir-butir pertanyaan dalam kuesioner adalah:

1. Kuesioner $\mathrm{r}$ hitung (koefisien korelasi) harus positif dan lebih besar dari $r$ tabel (Product Moment Pearson).

2. Nilai $r$ hitung untuk masing- masing butir pertanyaaan bisa dilihat langsung pada output uji validitas pada kolom correct item- total correlation yang diperoleh dari hasil uji dua arah dengan alpha 5\% (interval kepercayaan 95\%).

3. Besarnya nilai $r$ tabel diperoleh dari tabel daftar nilai kritis Pearson Product Moment dengan menentukan nilai $\mathrm{D}_{\mathrm{F}}$ $($ Degree of Freedom $)=\mathrm{n}-2=41-2=39$, sehingga pada alpha 0,05 diperoleh $r$ tabel sebesar 0,3081.

Pengujian Validitas selengkapnya dapat dilihat pada Tabel 8. Hasilnya menunjukkan nilai koefisien korelatif positif tapi tidak lebih besar daripada nilai r-tabel. Pada uji validitas lanjutan, keseluruhan item pernyataan yang tersisa memiliki nilai koefisien korelatif positif lebih besar dari nilai r-tabel. Hal ini menunjukkan bahwa semua pernyataan dinyatakan telah valid.

\section{b. Uji Reliabilitas}

Uji reliabilitas digunakan untuk menguji sejauh mana keandalan suatu alat pengukur untuk dapat digunakan lagi pada penelitian yang sama. Pengujian reliabilitas dalam penelitian ini adalah dengan menggunakan rumus Alpha. Uji reliabilitas 
Tabel 8. Hasil Pengujian Validitas

\begin{tabular}{|c|c|c|c|c|}
\hline No & Variabel/ Pernyataan & $\begin{array}{c}\text { Pearson } \\
\text { Correlation }\end{array}$ & rTabel & Keterangan \\
\hline \multicolumn{5}{|c|}{ Integritas Dalam Prinsip Etika IAI } \\
\hline 1 & Pernyataan 1 & 0.506 & 0.3081 & Valid \\
\hline 2 & Pernyataan 3 & 0.469 & 0.3081 & Valid \\
\hline 3 & Pernyataan 4 & 0.576 & 0.3081 & Valid \\
\hline 4 & Pernyataan 5 & 0.429 & 0.3081 & Valid \\
\hline 5 & Pernyataan 6 & 0.439 & 0.3081 & Valid \\
\hline 6 & Pernyataan 7 & 0.423 & 0.3081 & Valid \\
\hline 7 & Pernyataan 10 & 0.525 & 0.3081 & Valid \\
\hline \multicolumn{5}{|c|}{ Integritas Dalam Aturan Etika IAI } \\
\hline 8 & Pernyataan 1 & 0.694 & 0.3081 & Valid \\
\hline 9 & Pernyataan 2 & 0.660 & 0.3081 & Valid \\
\hline 10 & Pernyataan 3 & 0.360 & 0.3081 & Valid \\
\hline \multicolumn{5}{|c|}{ Integritas Dalam Interpretasi Aturan Etika IAI } \\
\hline 11 & Pernyataan 1 & 0.585 & 0.3081 & Valid \\
\hline 12 & Pernyataan 2 & 0.497 & 0.3081 & Valid \\
\hline
\end{tabular}

Sumber : Data Primer Diolah, 2018

Tabel 9. Hasil Pengujian Reliabilitas

\begin{tabular}{|c|c|c|c|c|}
\hline No & Variabel/ Pernyataan & $\begin{array}{l}\text { Cronbach's Alpha } \\
\text { If Item Deleted }\end{array}$ & $\begin{array}{l}\text { Cronbach } \\
\text { Alpha }\end{array}$ & Keterangan \\
\hline \multicolumn{5}{|c|}{ Integritas Dalam Prinsip Etika IAI } \\
\hline 1 & Pernyataan 1 & 0,697 & 0,60 & Reliabel \\
\hline 2 & Pernyataan 3 & 0,712 & 0,60 & Reliabel \\
\hline 3 & Pernyataan 4 & 0,688 & 0,60 & Reliabel \\
\hline 4 & Pernyataan 5 & 0,709 & 0,60 & Reliabel \\
\hline 5 & Pernyataan 6 & 0,711 & 0,60 & Reliabel \\
\hline 6 & Pernyataan 7 & 0,712 & 0,60 & Reliabel \\
\hline 7 & Pernyataan 10 & 0,695 & 0,60 & Reliabel \\
\hline \multicolumn{5}{|c|}{ Integritas Dalam Aturan Etika IAI } \\
\hline 8 & Pernyataan 11 & 0,676 & 0,60 & Reliabel \\
\hline 9 & Pernyataan 12 & 0,671 & 0,60 & Reliabel \\
\hline 10 & Pernyataan 13 & 0,735 & 0,60 & Reliabel \\
\hline \multicolumn{5}{|c|}{ Integritas Dalam Interpretasi Aturan Etika IAI } \\
\hline 11 & Pernyataan 14 & 0,686 & 0,60 & Reliabel \\
\hline 12 & Pernyataan 15 & 0,703 & 0,60 & Reliabel \\
\hline
\end{tabular}

dilakukan dengan melihat hasil dari Cronbach's Alpha Coefficient diatas 0,60 (mendekati angka satu), maka item-item dalam kuesioner semakin reliabel (konsisten). Hasil uji reliabilitas data untuk sisa 12 pernyataan yang tersisa ditunjukkan dalam Tabel 9.

Berdasarkan uji reliabilitas sesuai dengan Tabel 9, dapat disimpulkan bahwa seluruh item pernyataan reliabel. Hal ini bisa dilihat dari keseluruhan item pernyataan memiliki nilai cronbach's alpha di atas 0,60.
Sehingga keseluruhan item pernyataan yang tersisa telah valid dan reliabel.

\subsubsection{Statistik Deskriptif}

Penelitian ini bertujuan untuk untuk mengetahui persepsi masyarakat pengguna jasa akuntan publik terhadap tingkat integritas akuntan publik di kota Makassar. Persepsi masyarakat pengguna jasa akuntan publik 16 item pernyataan kuesioner. Namun setelah melalui pengujian validitas dan reliabilitas, maka item pernyataan yang dianggap valid dan reliabel sebanyak 12 pernyataan dengan menggunakan 
skala likert dari pilihan jawaban sangat tidak setuju (dengan skor 1) sampai dengan sangat setuju (dengan skor 5). Terdapat 41 responden masyarakat pengguna jasa akuntan publik yang mengembalikan kuesioner terdiri dari 19 responden perusahaan go public, dua responden perusahaan sekuritas, dan 20 responden bank konvensional.

Untuk mengetahui persepsi masyarakat pengguna jasa akuntan publik terhadap tingkat integritas akuntan publik, peneliti menggunakan analisis statistik deskriptif, yaitu membagi keseluruhan item pernyataan menjadi tiga kelompok berdasarkan hierarki integritas tersebut, yaitu :

1. Persepsi masyarakat pengguna jasa akuntan publik terhadap integritas KAP sesuai dengan prinsip etika IAI/ pada prinsip ketiga (pernyataan nomor 1, 3, 4, 5, 6, 7, dan 10).

2. Persepsi masyarakat pengguna jasa akuntan publik terhadap integritas KAP sesuai dengan aturan etika No. 100 (pernyataan nomor 11, 12, dan 13).

3. Persepsi masyarakat pengguna jasa akuntan publik terhadap integritas KAP sesuai dengan interpretasi aturan etika akuntan Indonesia (pernyataan nomor 14 dan 15).

a. Integritas Dalam Prinsip Etika IAI (Prinsip Ketiga)

Prinsip ini meminta komitmen untuk berperilaku terhormat, bahkan dengan pengorbanan keuntungan pribadi. Di dalam prinsip etika, dimana integritas ditetapkan sebagai salah satu prinsip, yakni pada prinsip ketiga etika IAI. Maka peneliti ingin menganalisis bagaimana persepsi masyarakat, khususnya masyarakat pengguna jasa akuntan publik terhadap tingkat integritas akuntan publik berdasarkan prinsip ketiga dalam prinsip etika IAI. Berikut adalah tabel statistik deskriptif integritas dalam prinsip etika IAI (prinsip ketiga):

Dari Tabel 10, mengenai integritas KAP sehubungan dengan integritas dalam prinsip etika IAI (prinsip ketiga) dapat dideskripsikan sebagai berikut :

1. Pada item pernyataan nomor 1 , dapat disimpulkan pada item pernyataan nomor 1 memberikan jawaban sangat positif atau sangat setuju.

2. Pada item pernyataan nomor 3 , dapat disimpulkan pada item pernyataan nomor 3 memberikan jawaban yang positif atau setuju.

3. Pada item pernyataan nomor 4, dapat disimpulkan pada item pernyataan nomor 4 memberikan jawaban yang positif atau setuju.

4. Pada item pernyataan nomor 5, dapat disimpulkan pada item pernyataan nomor 5 memberikan jawaban yang positif atau setuju.

5. Pada item pernyataan nomor 6, dapat disimpulkan pada item pernyataan nomor 6 memberikan jawaban yang positif atau setuju.

Tabel 10. Hasil Statistik Deskriptif Integritas Dalam Prinsip Etika IAI (Prinsip Ketiga)

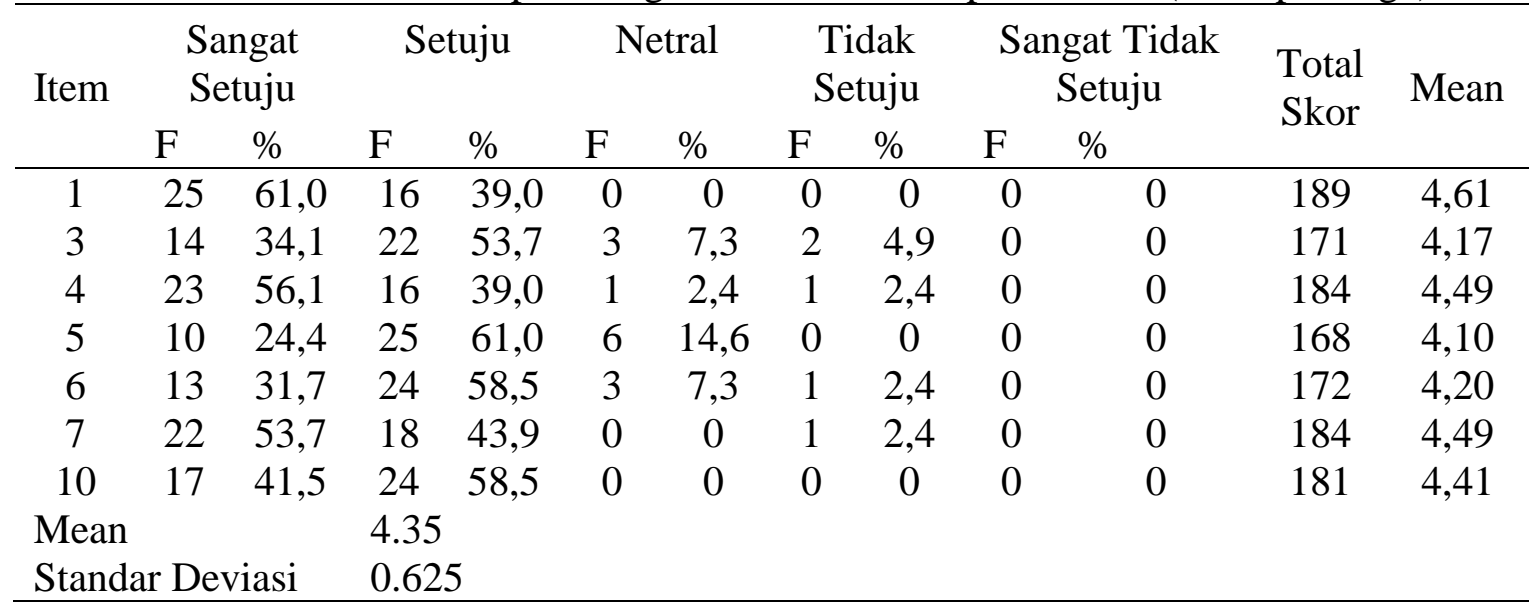


6. Pada item pernyataan nomor 7 , dapat disimpulkan pada item pernyataan nomor 7 memberikan jawaban yang positif atau setuju

7. Pada item pernyataan nomor 10 , dapat disimpulkan pada item pernyataan nomor 10 memberikan jawaban yang positif atau setuju.

Dari keseluruhan item kesimpulannya adalah bahwa persepsi masyarakat pengguna jasa akuntan publik terhadap tingkat integritas KAP di Makassar sehubungan dengan integritas dalam prinsip etika profesi dalam kode etik IAI adalah positif atau masih dalam tingkat integritas yang tinggi.

b. Integritas Dalam Aturan Etika Nomor 100

Aturan etika harus diterapkan oleh anggota Ikatan Akuntan Indonesia (IAI) dan staf profesional. Salah satunya mengenai integritas dan objektivitas. Sehubungan dengan hal ini, maka peneliti ingin menganalisis persepsi masyarakat pengguna jasa akuntan publik terhadap tingkat integritas KAP berdasarkan aturan etika IAI No. 100. Berikut adalah tabel statistik deskriptif integritas sehubungan dengan aturan etika No. 100.
Dari Tabel 11, mengenai integritas KAP sehubungan dengan integritas dalam aturan etika IAI No.100 dapat dideskripsikan sebagai berikut:

1. Pada item pernyataan nomor 11 , memberikan jawaban sangat positif atau sangat setuju.

2. Pada item pernyataan nomor 12 , memberikan jawaban yang positif atau setuju.

3. Pada item pernyataan nomor 13 , memberikan jawaban yang positif atau setuju.

Dari keseluruhan item pernyataan positif atau setuju. Kesimpulannya adalah bahwa persepsi masyarakat pengguna jasa akuntan publik terhadap tingkat integritas KAP di Makassar sehubungan dengan integritas dalam aturan etika IAI No. 100 adalah positif atau masih dalam tingkat integritas yang tinggi.

\section{c. Integritas Dalam Interpretasi Aturan} Etika IAI

Interpretasi aturan etika akuntan publik, salah satu komponen penting di dalam hal tersebut adalah pengimplementasian integritas. Berikut adalah tabel statistik deskriptif integritas sehubungan dengan interpretasi aturan etika.

Tabel 11. Hasil Statistik Deskriptif Integritas Dalam Aturan Etika IAI Nomor 100

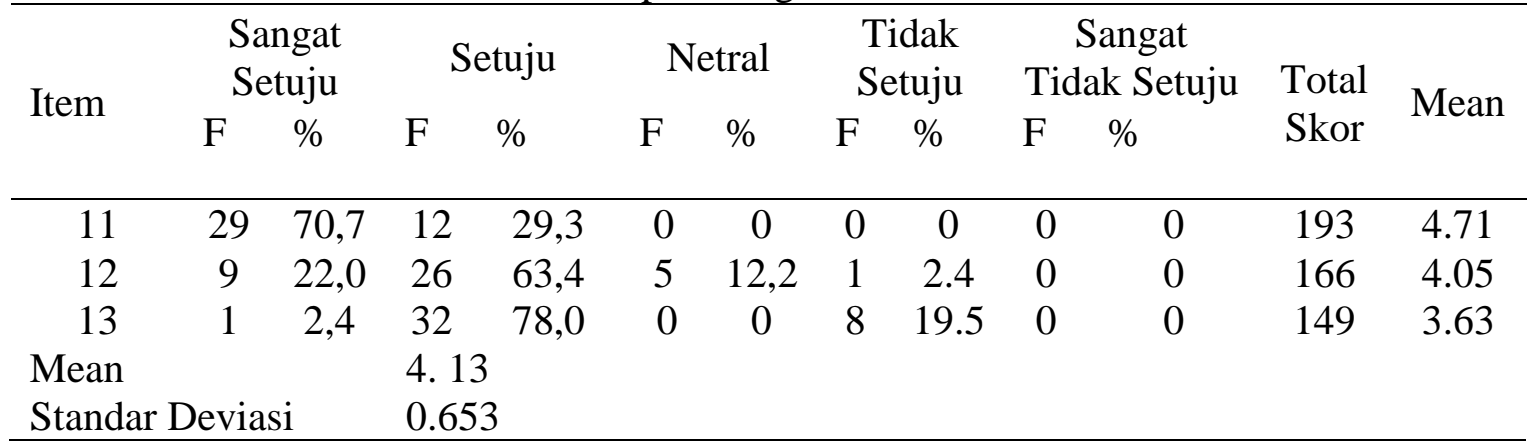

Tabel 12. Hasil Statistik Deskriptif Integritas Dalam Interpretasi Aturan Etika IAI

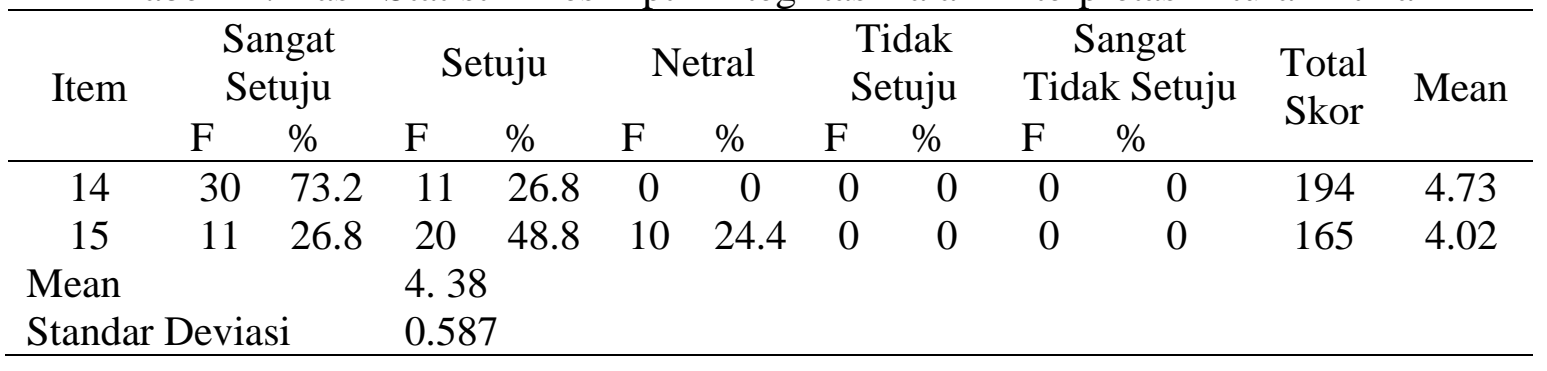


Berdasarkan Tabel 2, mengenai integritas KAP sehubungan dengan integritas dalam interpretasi aturan etika Ikatan Akuntan Indonesia (IAI) dapat dideskripsikan sebagai berikut:

1. Pada item pernyataan nomor 14 , memberikan jawaban sangat positif atau sangat setuju.

2. Pada item pernyataan nomor 15 , dapat disimpulkan pada item pernyataan nomor 15 memberikan jawaban yang positif atau setuju.

Dari keseluruhan item pernyataan positif atau setuju. Kesimpulannya adalah bahwa persepsi masyarakat pengguna jasa akuntan publik terhadap tingkat integritas KAP di Makassar sehubungan dengan integritas dalam interpretasi aturan etika IAI adalah positif atau masih dalam tingkat integritas yang tinggi.

\subsection{Pembahasan}

Pada penelitian ini, kuesioner yang dibagikan kepada responden masyarakat pengguna jasa akuntan publik disesuaikan dengan jumlah sampel yang telah ditetapkan, yaitu sebanyak 43 kuesioner. Item-item pertanyaan yang diajukan adalah pertanyaan yang bersifat tertutup atau pertanyaan dengan pilihan jawaban yang sudah ditentukan sebelumnya, yakni dari sangat setuju dengan skor lima sampai sangat tidak setuju dengan skor satu yang diukur dengan menggunakan skala likert. Adapun kelompok pertanyaan di dalam kuesioner sehubungan dengan tingkat integritas akuntan publik secara garis besar dapat dibagi menjadi tiga bagian berdasarkan hierarki etika profesional akuntan publik, yaitu integritas berdasarkan prinsip etika IAI, aturan etika IAI, dan interpretasi aturan etika IAI.

Integritas sebagai salah satu unsur penting di dalam etika profesional akuntan publik dimana etika profesional dikeluarkan oleh organisasi profesi untuk mengatur perilaku anggotanya di dalam menjalankan praktek profesinya bagi masyarakat seringkali menghadapi dilema etika atau situasi yang dihadapi dimana harus mengambil keputusan tentang perilaku yang tepat. Dimana hal tersebut dapat terjadi diantaranya karena imbalan ekonomis yang dijanjikan, hubungan yang erat dengan klien, atau rasionalisasi hal tersebut karena dianggap perilaku yang dapat diterima. Dengan pengambilan keputusan yang salah atau dimana akuntan publik gagal dalam menghadapi dilema etikanya, tentunya akan berpengaruh terhadap tingkat integritasnya.

Banyaknya kasus dilema etika yang dihadapi oleh akuntan publik akhir-akhir ini, Widagdo, Lesmana, dan Irwandi (2002) mengeksplorasi dampak dari 12 atribut (pengalaman audit, pengetahuan industri, kepatuhan terhadap standar audit, independensi, standar etika yang tinggi, komitmen terhadap kualitas audit, audit komite, skeptisisme audit, responsif terhadap tuntutan klien, reputasi audit mitra, kehati-hatian dan keakuratan) pada kepuasan klien dengan layanan audit dan ditemukan lima atribut, yaitu, independensi auditor, kehati-hatian, akurasi, etika tinggi standar dan skeptisisme auditor, karena tidak mempengaruhi kepuasan dengan layanan audit.

Hubungan yang begitu dekat antara pemerintah dan profesi dapat mempengaruhi persepsi yang dipegang oleh berbagai kelompok dalam masyarakat tentang situasi yang mempengaruhi independensi auditor (Irmawan, Hudaib, \& Haniffa, 2013). Beberapa contoh kasus telah disebutkan sebelumnya yang tidak jarang melibatkan kantor akuntan publik yang memiliki tingkat integritas yang tinggi di masyarakat pengguna jasa akuntan publik, maka peneliti ingin mengetahui bagaimana persepsi masyarakat pengguna jasa akuntan publik terhadap tingkat integritas akuntan publik di kota Makassar. Jawaban responden berdasarkan hasil statistik deskriptif untuk integritas akuntan publik berdasarkan prinsip etika IAI pada prinsip ketiga sebagian besar memberikan jawaban positif atau setuju pada lembar kuesioner. Untuk integritas akuntan publik berdasarkan aturan etika IAI nomor 100 juga sebagian besar memberikan jawaban positif atau setuju pada 
lembar kuesioner dan integritas akuntan publik berdasarkan interpretasi dari aturan etika IAI juga memberikan jawaban positif atau setuju.

Berdasarkan penelitian terdahulu yang dilakukan Rasyid (2004), persepsi masyarakat pengguna jasa akuntan publik terkait dengan tingkat independensi, integritas, dan objektivitas akuntan publik juga menunjukkan hasil yang positif. Hal tersebut mengindikasikan bahwa secara umum, terlepas dari berbagai kasus dilema etika yang terjadi akhir-akhir ini, persepsi masyarakat pengguna jasa akuntan publik terhadap tingkat integritas akuntan publik di kota Makassar masih dalam tingkat integritas yang tinggi dikarenakan jumlah akuntan publik yang cenderung masih sedikit sehingga independensi para akuntan publik sejauh ini masih tetap terjaga.

\section{Kesimpulan}

Berdasarkan hasil penelitian yang telah dilakukan, yaitu untuk mengetahui persepsi masyarakat pengguna jasa akuntan publik atau masyarakat pengguna laporan keuangan yang telah diaudit yaitu pihak internal yang terdiri dari direktur atau manajer perusahaan go public dan pihak eksternal yang terdiri dari investor dan kreditor terhadap integritas akuntan publik di kota Makassar menunjukkan hasil yang positif atau memiliki tingkat integritas yang tinggi. Selain itu dari hasil penelitian ini, dapat disimpulkan bahwa sebagian besar masyarakat pengguna jasa akuntan publik memiliki tingkat kepuasan yang positif atas kinerja akuntan publik di kota Makassar. Pada hasil statistik deskriptif dimana persepsi masyarakat pengguna jasa akuntan publik terhadap tingkat integritas akuntan publik sehubungan dengan Prinsip Etika IAI (Prinsip Ketiga), Aturan Etika Nomor 100, dan Interpretasi Aturan Etika IAImenunjukkan nilai mean sebesar empat berarti sebagian besar responden memberikan jawaban positif atau setuju terhadap lembar jawaban kuesioner.

\section{Ucapan Terimakasih}

Alhamdulilah panjatkan karena izin dan rahmat Allah swt sehingga Tulisan ini dapat terselesaikan dan juga tak lupa Terima kasih kepada semua para manager dan direktur perusahaan sebagai pengguna jasa akuntan publik, yang telah meluangkan waktu untuk mengisi kuesioner sehingga dapat terselesainya tulisan.

\section{Daftar Pustaka}

Agoes, S., \& Ardana, C. (2009). Etika bisnis dan profesi: Tantangan Membangun Manusia Seutuhnya. Jakarta: Salemba Empat.

Alvin, A. A., Ellder, J. R., \& Beasley, M. S. (2008). Auditing dan Jasa Assurance: Pendekatan Terintegrasi. Penerbit Erlangga, Jakarta.

Bachtiar, E. (2001, August). Nationalism in Professionalization of Indonesian Accountancy. In Second Accounting History International Conference. Osaka (pp. 8-10).

Chaplin, J. P. (2006). Kamus lengkap psikologi (terjemahan Kartini Kartono). Jakarta: PT Raja Grafindo Persada.

Fred, L. (2006). Perilaku organisasi. Edisi Sepuluh. Yogyakarta. Penerbit Andi.

Husein, U. (2009). Metode penelitian untuk skripsi dan tesis bisnis. Jakarta: PT Raja Grafindo Persada.

Irmawan, Y., Hudaib, M., \& Haniffa, R. (2013). Exploring the perceptions of auditor independence in Indonesia. Journal of Islamic Accounting and Business Research, 4(2), 173-202.

Jusup, A. H., (2001). Auditing (Pengauditan). Jakarta: STIE YKPN.

Lubis, A. I. (2010). Akuntansi keperilakuan. Jakarta: Salemba Empat.

Porter, B., Simon, J., \& Hatherly, D. (2003). Principles of external auditing. John Wiley $\&$ Sons. New York: Wiley.

Robbins, S. P., \& Judge, T. A. (2008). Perilaku organisasi (Organizational behavior). Jakarta: Salemba Empat.

Rodgers, W., Mubako, G. N., \& Hall, L. (2017). Knowledge management: The effect of knowledge transfer on professional skepticism in audit engagement planning. Computers in Human Behavior, 70, 564-574. 
Sartika, D. (2006). Persepsi Dosen Akuntansi dan Mahasiswa Akuntansi Terhadap Kode Etik Akuntan. Fakultas Ekonomi Universitas Bengkulu

Sugiyono. (2003). Metode Penelitian Bisnis. Edisi 1, Bandung: Alfabeta.

Suhardi, S. (2012). Persepsi pemakai laporan keuangan pemerintah daerah terhadap independensi auditor Badan Pemeriksa
Keuangan. Jurnal Akuntansi Universitas Jember, 10(2).

Widagdo, R., Lesmana, S., \& Irwandi, S. A., (2002) (2002). Analisis Pengaruh atributatribut kualitas Audit terhadap kepuasan Klien: Studi Empiris pada Perusahaan yang Terdaftar di Bursa Efek Jakarta. Makalah Simposium Nasional Akuntansi, 5. 